\title{
Sikap Petani Anggota Subak terhadap Program Asuransi Usahatani Padi di Subak Yeh Embang, Desa Yeh Embang Kangin, Kecamatan Mendoyo, Kabupaten Jembrana
}

\author{
KADEK AGUS NOPTANDIKA KUSUMA, I GEDE SETIAWAN ADI PUTRA, \\ NYOMAN PARINING
}

\author{
Program Studi Agribisnis, Fakultas Pertanian, Universitas Udayana \\ Jalan PB. Sudirman Denpasar, 80323 \\ Email: agusnoptandika@gmail.com \\ igedesetiawanadiputra@gmail.com
}

\begin{abstract}
Subak Farmers' Attitudes toward Rice Farming Insurance Program in Subak Yeh Embang, Yeh Embang Kangin Village, Mendoyo Sub-district, Jembrana Regency

Food security becomes one of the main goals of national development. One of the efforts undertaken by the Jembrana Regency Government is to implement a special effort (UPSUS) which is the insurance program of paddy farming (AUTP) since 2015. Farmers of Subak Yeh Embang who have not followed the insurance program of rice farming is high (41.46\%). The purpose of this research is to investigate the attitude of the farmers of Subak Yeh Embang on paddy farming insurance program. The research was conducted in Subak Yeh Embang, Yeh Embang Kangin Village, Mendoyo Subdistrict, of Jembrana Regency. The respondents were 35 people from the population of 233 farmers who have not followed the paddy farming insurance program determined by using the Proportional Random Sampling method.

The findings showed that the attitude of farmers of Subak Yeh Embang can be categorized as agreed with the rice farming insurance by the score of 4.06. The farmers' attitude toward the objectives, targets, benefits, risks, and success of paddy farming insurance program included in the category of strongly agree, while farmers' attitude to compensation, compensation payment, coverage period, amount of claim, and the approval of the insurance claim are included in the category agreed, and the attitude of farmers to the organization of the implementation of rice farming insurance program was the category of doubtful.

Based on the result of the research, it is expected that the extension agents and related institutions should be more active in conducting counseling and dissemination of information about rice insurance program (AUTP).
\end{abstract}

Keywords: attitude, subak, rice farming, insurance program 


\section{Pendahuluan}

\subsection{Latar Belakang}

Ketahanan pangan nasional menjadi salah satu tujuan utama pembangunan nasional. Kekurangan bahan pangan, khususnya bahan makanan pokok beras akan menimbulkan gejolak sosial ekonomi dan politik yang memengaruhi pembangunan itu sendiri. Saat ini sangat diperlukan cara bagaimana mencapai ketahanan pangan pada tingkat kecukupan tertentu dalam keadaan ekonomi dan politik yang kurang menguntungkan, besarnya pengangguran, meluasnya kemiskinan, dan meningkatnya harga-harga pangan yang menurunkan posisi tawar petani. Produksi pangan, khususnya beras sudah seharusnya ditingkatkan dan distabilkan (Pasaribu, 2005). Bali memiliki lembaga bernama subak. Fungsi utama subak untuk mengelola air dan memproduksi pangan. subak tidak terlepas dari kegiatan pengelolaan air irigasi untuk bercocok tanam padi, maka tidak keliru jika dikatakan bahwa subak identik dengan budidaya padi (Pitana dan Setiawan, 2004).

Swasembada padi dengan target produksi padi tahun 2016 mencapai 75,13 juta ton. Usaha di sektor pertanian khususnya usahatani padi dihadapkan pada risiko ketidakpastian sebagai akibat dampak negatif perubahan iklim. Mengatasi kerugian petani, maka pemerintah membantu mengupayakan perlindungan usahatani dalam bentuk asuransi pertanian, sebagaimana tercantum pada Undang-Undang Nomor 19 Tahun 2013 tentang Perlindungan dan Pemberdayaan Petani, yang telah ditindaklanjuti dengan penerbitan Peraturan Menteri Pertanian No 40 Tahun 2015 tentang Fasilitasi Asuransi Pertanian. Asuransi pertanian sangat penting bagi para petani untuk melindungi usahataninya (Direktorat Jendral Prasarana dan Sarana Pertanian, 2016).

Asuransi merupakan suatu alat untuk mengurangi resiko keuangan, dengan cara pengumpulan unit-unit dalam jumlah yang memadai untuk membuat agar kerugian individu dapat diperkirakan kemudian kerugian yang dapat diramalkan itu dipikul merata oleh mereka yang bergabung. Setiap pengikut asusansi akan mendapatkan kartu polis, sebagai tanda bahwa orang tersebut masuk dalam asuransi dan wajib membayar premi asuransi yang besarnya telah ditetapkan oleh perusahaan sesuai dengan perjanjian. Inilah yang menyebabkan timbulnya piutang premi tidak tertagih yang berdampak pada penghentian pertanggungan akibat tidak dibayarkannya premi-premi (polis lapse), dampaknya disini terlihat jika seorang nasabah tidak membayarkan premipreminya sampai tiga bulan sehingga menyebabkan polis lapse (Cammack, 1981).

Pemerintah Kabupaten Jemberana melalui Dinas Pertanian, telah melaksanakan salah satu kegiatan upaya khusus (UPSUS) yaitu program Asuransi Usahatani Padi sejak tahun 2015. Program ini difokuskan untuk melindungi kerugian nilai ekonomi usahatani padi akibat gagal panen, sehingga petani memiliki modal kerja untuk pertanaman berikutnya. Kerusakan komuditas padi di Kabupaten Jembrana total luasnya mencapai 7,02 ha yang diakibatkan oleh kekeringan, wereng coklat, dan penyakit blast. Subak Yeh Embang sendiri kerusakan komuditas padi luahnya mencapai 1,34 ha yang diakibatkan oleh wereng coklat (Dinas Pertanian Kabupaten Jembrana, 2016 a). 
Menurut Gerungan (1983), sikap mempunyai ciri-ciri sebagai berikut. a) Sikap bukan dibawa sejak lahir, melainkan dibentuk atau dipelajarinya sepanjang perkembangan manusia dalam hubungannya dengan lingkungan, b) Sikap itu dapat berubah-ubah, karena itu sikap dapat dipelajari bila didukung oleh keadaan, dan c) Sikap tidak berdiri sendiri, tetapi senantiasa mengandung relasi tertentu terhadap suatu objek. Sikap itu terbentuk atau berubah-ubah berkenaan dengan suatu objek. Petani anggota Subak Yeh Embang yang sudah mengikuti Asuransi Usahatani Padi sebanyak $329(58,54 \%)$ orang dari jumlah keseluruhan petani anggota Subak Yeh Embang 562 orang. Sebanyak $233(41,46 \%)$ orang jumlah petani Subak Yeh Embang yang belum mengikuti program Asuransi Usahatani Padi, karena minat dari petani itu untuk mengikuti program AUTP masih rendah (Dinas Pertanian Kabupaten Jembrana, 2016 b). Minat petani untuk mengikuti program asuransi usahatani padi dipengaruhi oleh sikap petani itu sendiri.

Berdasarkan uraian latar belakang tersebut maka penulis tertarik untuk mengkaji lebih dalam lagi, dengan melakukan penelitian mengenai sikap petani anggota subak terhadap program asuransi usahatani padi di Subak Yeh Embang, Desa Yeh Embang Kangin, Kecamatan Mendoyo, Kabupaten Jembrana.

\subsection{Rumusan Masalah}

Sesuai dengan latar belakang di atas, maka dapat dirumuskan permasalahan dalam penelitian ini yaitu bagaimana sikap petani anggota subak terhadap program asuransi usahatani padi di Subak Yeh Embang, Desa Yeh Embang Kangin, Kecamatan Mendoyo, Kabupaten Jembrana.

\subsection{Tujuan Penelitian}

Berdasarkan rumusan masalah di atas, maka penelitian ini bertujuan untuk mengetahui sikap petani anggota subak terhadap program asuransi usahatani padi di Subak Yeh Embang, Desa Yeh Embang Kangin, Kecamatan Mendoyo, Kabupaten Jembrana.

\section{Metode Penelitian}

\subsection{Lokasi dan Waktu Penelitian}

Penelitian ini dilakukan di Subak Yeh Embang, Desa Yeh Embang Kangin, Kecamatan Mendoyo, Kabupaten Jembrana. Waktu penelitian berlangsung dari bulan Juni sampai dengan September 2017. Adapun pertimbangan pemilihan lokasi penelitian, karena kurangnya kesadaran petani sebanyak 233 (41,46\%) orang di Subak Yeh Embang untuk mengikuti asuransi usahatani padi.

\subsection{Jenis dan Sumber Data}

Data dalam penelitian diperoleh dari data primer yang berupa wawancara atau kuisioner yang disebarkan kepada sejumlah responden seperti, Kelihan dan Petani aktif di Subak Yeh Embang, Desa Yeh Embang Kangin, Kecamatan Mendoyo, Kabupaten Jembrana, dan data sekunder yang berupa literatur, artikel, jurnal, situs di internet, 
gambaran umum daerah penelitian, dan kelembagaan subak. Jenis data yang digunakan adalah data kualitatif yaitu menjelaskan mengenai sikap petani anggota subak terhadap program asuransi usahatani padi di Subak Yeh Embang, Desa Yeh Embang Kangin, Kecamatan Mendoyo, Kabupaten Jembrana dan data kuantitatif diperoleh dengan data skor.

\subsection{Populasi dan Sampel (Responden)}

Populasi dalam penelitian ini seluruh petani aktif Subak Yeh Embang yang belum mengikuti program asuransi usahatani padi berjumlah 233 orang petani. Penetapan pengambilan responden menggunakan metode simple random sampling, dilakukan dengan presentase 15\% mewakili representasi populasi aktif sebesar 233 orang, sehingga total responden menjadi 35 orang petani. Proportional random sampling adalah pengambilan sampel secara proporsi yang dilakukan dengan mengambil subjek dari setiap strata atau setiap wilayah ditentukan seimbang dengan banyaknya subjek dalam masing-masing strata atau wilayah (Arikunto, 2006).

\subsection{Pengumpulan Data}

Pengumpulan data dalam penelitian ini melalui wawancara dan wawancara mendalam. Wawancara dikemukan oleh Sugiyono (2012), digunakan sebagai teknik pengumpulan data apabila peneliti ingin melakukan studi pendahuluan untuk menemukan permasalahan yang harus diteliti dan mengajukan pertanyaan secara lisan kepada informan kunci dan wawancara mendalam (indepth interview) merupakan proses mencari informasi yang dilakukan dengan tatap muka (face to face) antara pewawancara dengan informan kunci atau narasumber, dengan instrumen penelitian, yaitu panduan wawancara (guide) (Sutopo, 2006). Wawancara dan wawancara mendalam dilakukan kepada petani anggota subak sebanyak 35 orang, PPL, dan pekaseh di Subak Yeh Embang. Wawancara terstruktur dengan kuesioner kepada petani sebanyak 35 orang.

\subsection{Variabel, Indikator, Parameter, dan Pengukuran}

Variabel penelitian ini untuk mengetahui sikap anggota subak terhadap program asuransi usahatani padi di Subak Yeh Embang, Desa Yeh Embang Kangin, Kecamatan Mendoyo, Kabupaten Jembrana. Indikator sikap meliputi, tujuan, sasaran, manfaat, resiko yang dijamin, keberhasilan, ganti rugi, pembayaran ganti rugi, jangka waktu pertanggungan, besar tanggungan, ketentuan klaim, persetujuan klaim, dan organisasi pelaksanaan program asuransi usahatani padi dengan parameter berdasarkan pedoman program AUTP, yang diukur menggunakan skor.

\subsection{Metode Analisis Data}

Dikemukakan oleh Sugiyono, (2010) analisis data merupakan proses mencari dan menyusun secara sistematis data yang diperoleh dari hasil wawancara, catatan lapangan, dan dokumentasi. Penelitian ini akan dianalisis dengan menggunakan metode analisis deskriptif kualitatif, diperoleh dari hasil penelitian berupa data kualitatif dan kuantitatif 
akan disajikan dalam bentuk narasi dan tabel yang disusun secara sistematis, dan efisien. Distribusi interval kelas kategori sikap dalam hasil persentase skor sebagai berikut. Interval kelas (1) 1,00-1,80 sangat tidak setuju, (2) >1,80-2,60 tidak setuju, (3) $>2,60-3,40$ ragu, (4) >3,40-4,20 setuju, dan (5) >4,20-5,00 sangat setuju.

\section{Hasil dan Pembahasan}

\subsection{Sikap Petani terhadap Program Asuransi Usahatani Padi}

Pengukuran sikap dapat dilakukan secara langsung dan tidak langsung. Secara langsung dapat dinyatakan bagaimana pendapat atau pertanyaan responden terhadap suatu objek atau juga dapat dilakukan dengan cara memberikan pendapat dengan menggunakan setuju atau tidak setuju terhadap pernyataan-pernyataan objek tertentu (Notoatmodjo, 2007).

Penelitian ini mengkaji tentang sikap petani anggota Subak Yeh Embang terhadap program asuransi usahatani padi dilihat dari tujuan, sasaran, manfaat, resiko, keberhasila, ganti rugi, pembayaran ganti rugi, jangka waktu, besar tanggungan, ketentuan klaim, persetujuan klaim, dan organisasi pelaksanaan. Secara rinci dapat dilihat pada Tabel 1 .

Tabel 1.

Sikap Petani Anggota Subak Yeh Embang Terhadap Program Asuransi Usahatani Padi, Tahun 2017

\begin{tabular}{|c|c|c|c|c|c|}
\hline No & Variabel & & Indikator & $\begin{array}{l}\text { Rata-rata } \\
\text { pencapaian } \\
\text { skor } \\
\end{array}$ & $\begin{array}{c}\text { Kategori } \\
\text { Sikap }\end{array}$ \\
\hline \multirow[t]{8}{*}{1} & Sikap & 1. & $\begin{array}{l}\text { Tujuan program } \\
\text { asuransi usahatani } \\
\text { padi }\end{array}$ & 4,53 & Sangat Setuju \\
\hline & & 2. & $\begin{array}{l}\text { Sasaran program } \\
\text { asuransi usahatani } \\
\text { padi }\end{array}$ & 4,48 & Sangat Setuju \\
\hline & & 3. & $\begin{array}{l}\text { Manfaat program } \\
\text { asuransi usahatani } \\
\text { padi }\end{array}$ & 4,42 & Sangat Setuju \\
\hline & & 4. & $\begin{array}{l}\text { Resiko yang dijamin } \\
\text { program asuransi } \\
\text { usahatani padi }\end{array}$ & 4,56 & Sangat Setuju \\
\hline & & 5. & $\begin{array}{l}\text { Keberhasilan } \\
\text { program asuransi } \\
\text { usahatani padi }\end{array}$ & 4,26 & Sangat Setuju \\
\hline & & & $\begin{array}{l}\text { Ganti rugi program } \\
\text { asuransi usahatani } \\
\text { padi }\end{array}$ & 3,91 & Setuju \\
\hline & & 7. & $\begin{array}{l}\text { Pembayaran ganti } \\
\text { rugi program asuransi } \\
\text { usahatani padi }\end{array}$ & 4,01 & Setuju \\
\hline & & & $\begin{array}{l}\text { Jangka waktu } \\
\text { pertanggungan } \\
\text { program asuransi } \\
\text { usahatani padi }\end{array}$ & 4,06 & Setuju \\
\hline
\end{tabular}


Lanjutan Tabel 1

Sikap Petani Anggota Subak Yeh Embang Terhadap Program Asuransi Usahatani Padi, Tahun 2017

\begin{tabular}{llcc}
\hline 9. & $\begin{array}{l}\text { Besar tanggungan } \\
\text { program asuransi } \\
\text { usahatani padi }\end{array}$ & 3,57 & Setuju \\
10. $\begin{array}{l}\text { Ketentuan klaim } \\
\text { program asuransi } \\
\text { usahatani padi }\end{array}$ & 3,99 & Setuju \\
11. $\begin{array}{l}\text { Persetujuan klaim } \\
\text { program asuransi } \\
\text { usahatani padi } \\
\text { Organisasi } \\
\text { pelaksanaan program } \\
\text { asuransi usahatani } \\
\text { padi }\end{array}$ & 3,86 & Setuju \\
& 3,07 & Ragu-ragu \\
\hline $\begin{array}{l}\text { Sikap petani terhadap program asuransi } \\
\text { usahatani padi }\end{array}$ & 4,06 & Setuju \\
\hline
\end{tabular}

Hasil penelitian menunjukkan bahwa sikap petani anggota Subak Yeh Embang terhadap program asuransi usahatani padi dilihat dari tujuan, sasaran dan manfaat, resiko, keberhasila, ganti rugi, pembayaran ganti rugi, jangka waktu, besar tanggungan, ketentuan klaim, persetujuan klaim, dan organisasi pelaksanaan pencapaian skornya sebesar 4,06 termasuk dalam kategori setuju dengan perincian sebagai berikut.

1. Sikap petani terhadap tujuan program asuransi usahatani padi dengan pencapaian skor 4,53 termasuk kategori sangat setuju, dikarenakan tujuan program usahatani padi mengalihan kerugian dan memberikan perlindungan kepada petani jika terjadi gagal panen akibat resiko banjir, kekeringan dan serangan OPT.

2. Sikap petani terhadap sasaran program asuransi usahatani padi dengan pencapaian skor 4,48 termasuk kategori sangat setuju, dikarenakan sasaran program asuransi usahatani padi terlindunginya petani dari kerugian dan teralihkannya petani dari kerugian jika gagal panen akibat resiko banjir, kekeringan, dan serangan OPT.

3. Sikap petani terhadap manfaat program asuransi usahatani padi dengan pencapaian skor 4,42 termasuk kategori sangat setuju, karena dapat memberikan manfaat yang baik seperti memperoleh ganti rugi keuangan sebagai modal kerja usahatani, meningkatkan aksesibilitas petani terhadap sumber-sumber pembiayaan, serta mendorong petani untuk menggunakan input produksi sesuai anjuran usahatani yang baik.

4. Sikap petani terhadap resiko yang dijamin program asuransi usahatani padi dengan pencapaian skor 4,56 termasuk kategori sangat setuju, karena resiko yang dijamin sangat membantu petani jika terjadi kerusakan oleh banjir, kekeringan, dan serangan OPT.

5. Sikap petani terhadap keberhasilan program asuransi usahatani padi dengan pencapaian skor 4,26 termasuk kategori sangat setuju, karena petani bersedia membayar premi asuransi serta prosedur penyaluran bantuan yang sesuai dengan 
petunjuk teknis penyaluran bantuan premi asuransi dan petani mendapat perlindungan asuransi bila gagal panen.

6. Sikap petani terhadap ganti rugi program asuransi usahatani padi dengan pencapaian skor 3,91 termasuk kategori setuju terhadap ketentuan ganti rugi yang meliputi umur padi yang sudah melewati 10 hari setelah masa tanam dan 30 hari (teknologi tabela),

7. Sikap petani terhadap pembayaran ganti rugi program asuransi usahatani padi dengan pencapaian skor 4,01 termasuk kategori setuju terhadap ketentuan pembayaran ganti rugi yang meliputi pembayaran atas klaim yang diajukan akibat gagal panen diukur sesuai dengan tingkat kerusakan yang terjadi, dan pembayaran ganti rugi atas klaim dilaksanakan paling lambat 14 (empat belas) hari kalender sejak berita acara hasil pemeriksaan kerusakan.

8. Sikap petani terhadap jangka waktu pertanggungan program asuransi usahatani padi dengan pencapaian skor 4,06 termasuk kategori setuju terhadap ketentuan penerbitan polis untuk satu musim tanam dengan jangka waktu pertanggungan dimulai pada tanggal perkiraan tanam dan berakhir pada tanggal perkiraan panen.

9. Sikap petani terhadap besar tanggungan program asuransi usahatani padi dengan pencapaian skor 3,57 termasuk kategori setuju terhadap besaran tanggungan yang diberikan sebesar Rp. 6.000.000 per hektar per musim tanam.

10. Sikap petani terhadap ketentuan klaim program asuransi usahatani padi dengan pencapaian skor 3,99 termasuk kategori setuju terhadap ketentuan-ketentuan klaim yang sudah ditetapkan seperti tertanggung menyampaikan secara tertulis pemberitahuan kejadian kerusakan kepada PPL/POPT-PHP dan petugas asuransi tentang indikasi terjadinya kerusakan (banjir, kekeringan dan OPT pada tanaman padi yang diasuransikan selambat-lambatnya 7 (tujuh) hari kalender setelah diketahui terjadinya kerusakan, tertanggung tidak diperkenankan menghilangkan bukti kerusakan tanaman sebelum petugas asuransi dan penilai kerugian melakukan pemeriksaan, saran pengendalian diberikan oleh PPL/POPT-PHP dan asuransi pelaksana dalam upaya menghindari kerusakan yang lebih luas, tertanggung mengambil langkah-langkah pengendalian yang dianggap perlu bersama-sama dengan petugas dinas pertanian setempat untuk menghindari kerusakan tanaman yang lebih luas, dan berita acara hasil pemeriksaan kerusakan diisi oleh tertanggung dengan melampirkan bukti kerusakan (foto-foto kerusakan) ditandatangani oleh tertanggung, POPT, dan petugas dari asuransi pelaksana, serta diketahui oleh Dinas Pertanian Kabupaten/Kota.

11. Sikap petani terhadap persetujuan klaim program asuransi usahatani padi dengan pencapaian skor 3,86 termasuk kategori setuju terhadap ketentuan persetujuan klaim yang meliputi jika dalam waktu 30 hari kalender sejak pemberitahuan kejadian kerusakan, belum terbit berita acara hasil pemeriksaan kerusakan, maka asuransi pelaksana dinyatakan setuju terhadap klaim yang diajukan.

12. Sikap petani terhadap organisasi pelaksanaan program asuransi usahatani padi dengan pencapaian skor 3,07 termasuk kategori ragu, karena lebih setuju 
organisasi program asuransi usahatani padi dilaksanakan oleh pemerintah dari pada dilaksanakan oleh pihak swata.

Sikap petani terhadap program asuransi usahatani padi adalah setuju, namun masih ada petani yang belum mengikuti program asuransi usahatani padi. Berdasarkan wawancara dengan pekaseh Subak Yeh Embang, petani yang belum mengikuti program asuransi usahatani padi dikarenakan petani sudah mampu memprediksi masalah atau hambatan pada saat musim tanam pada saat itu, kesadaran petani untuk mendaftar ikut program asuransi usahatani padi masih sangat kurang, dan kurangnya penyuluhan kepada petani tentang program asuransi usahatani padi.

\section{Simpulan dan Saran}

\subsection{Simpulan}

Berdasarkan hasil penelitian tentang sikap petani anggota subak terhadap program asuransi usahatani padi di Subak Yeh Embang, Desa Yeh Embang Kangin, Kecamatan Mendoyo, Kabupaten Jembrana dapat disimpulkan bahwa petani setuju dengan program asuransi usahatani padi dengan pencapaian skor 4,06.

\subsection{Saran}

Berdasarkan hasil pembahasan dan simpulan tersebut dapat disarankan sebagai berikut.

1. Petani Subak Yeh Embang sebanyak 233 orang masih ada yang belum mengikuti program asuransi usahatani padi, diharapkan untuk mengikuti program asuransi usahatani padi karena program tersebut dapat memberikan perlindungan kepada petani jika terjadi gagal panen.

2. Kepada instansi-instansi yang terkait dengan program asuransi usahatani padi, diharapkan untuk lebih intensif dalam melakukan penyuluhan dan penyebaran informasi kepada petani.

\section{Ucapan Terimakasih}

Ucapan terimakasih penulis ditujukan kepada semua pihak yang telah membantu penulis dalam melaksanakan penelitian hingga karya ilmiah ini dapat dipublikasikan dalam e-jurnal.

\section{Daftar Pustaka}

Arikunto. 2006. Prosedur Penelitian: Suatu Pendekatan Praktik. Rineka Cipta. Jakarta.

Cammack, M.D. 1981. Dasar-dasar Asuransi. Jakarta: Balai Aksara. http://digilib.mercubuana.ac.id/manager/n!@file_skripsi/Isi2951748478745.pdf.

Internet [Jurnal Online]. Diunduh pada tanggal 11 November 2016.

Dinas Pertanian Kabupaten Jembrana. 2016 a. Data Kerusakan Komuditas Padi di Jembrana.

Dinas Pertanian Kabupaten Jembrana. 2016 b. Data Peserta Asuransi Usahatani Padi. 
Direktorat Jendral Prasarana dan Sarana Pertanian. 2016. Pedoman Bantuan Premi Asuransi Usahatani Padi Tahun 2016. psp.pertanian.go.id/assets/file/2016/PEDUM\%20AUTP\%2015\%20Jan\%202016.p df. Internet [Online]. Diunduh pada tanggal 11 November 2016.

Gerungan, W.A. 1983. Psikologi Sosial Suatu Ringkasan. PT. Erosco. Bandung.

Notoatmodjo, S. 2007. Promosi Kesehatan \& Ilmu Perilaku. Jakarta: PT. Rineka Cipta.

Pasaribu, S.M. 2005. Pengembangan Asuransi Usahatani Padi Untuk Menanggulangi Risiko Kerugian 75\% Akibat Banjir, Kekeringan Dan Hama Penyakit. http://pse.litbang.pertanian.go.id/ind/pdffiles/MAKPROP_SHP.pdf [Jurnal Online] diunduh pada 29 November 2016.

Pitana dan Setiawan. 2004. Revitalisasi Subak Dalam Memasuki Era Globalisasi. Denpasar: Sosek Udayana.

Sugiyono. 2010. Metode Penelitian Pendidikan: Pendekatan Kuantitatif, Kualitatif dan $R \& D$. Bandung. Alfabeta.

Sugiyono. 2012. Metode Penelitian Kuantitatif Kualitatif dan R\&D. Alfabeta, Bandung. Sutopo. 2006. Metodologi Penelitian Kualitatif. UNS. Surakarta. 